\title{
ARQUEOLOGIA DA CRIAÇÃO EM MERLEAU-PONTY: PLÁSTICA DA DES-FIGURAÇÃO
}

Harley Juliano Mantovani*

\begin{abstract}
RESUMO
Esse texto eleva a princípio filosófico e hermenêutico a afirmação de Merleau-Ponty, segundo a qual as artes são uma Ursprungsklärung imposta à ciência e ao conhecimento tradicional. Na seqüência, analisamos a importância desse posicionamento teórico para o projeto ontológico de Merleau-Ponty. A questão foi: como a filosofia pode reencontrar o Ser? A Aisthesis foi seu caminho.
\end{abstract}

PALAVRAS-CHAVE: Merleau-Ponty. Ontologia. Estética. Metafísica. Teoria literária.

\begin{abstract}
This text raises to philosophical and hermeneutic principle MerleauPonty's affirmation, that arts are a Ursprungsklärung imposed to science and traditional knowledge. After that, we analyse the importance of this theoretical decision to Merleau-Ponty's ontological project. The question was this: how can Philosophy meet again the Being? The Aisthesis was his way.
\end{abstract}

KEYWORDS: Merleau-Ponty. Ontology. Aesthetics. Metaphysics. Literary theory.

Mestre em Filosofia pela Universidade Federal de São Carlos. Professor substituto do Departamento de Filosofia da UFU. 
A linguagem que não diz, diz a seu modo, eis a pintura. A linguagem ameaçada pela não-linguagem fala, eis a literatura.

\section{(...)}

Há pintura, ou melhor, a pintura se faz criação quando ela adentra num depois ameaçador que já não é significação e que é, portanto, busca de uma nova significação, que pressupõe uma "deformação coerente" dos dados do mundo. A pintura acontece ao pôr-se numa ausência de pontos de apoio, de pontos de vista; ela está no interior daquele não-Lugar, assistindo de dentro o nascimento ou deiscência deste.

Através dessa necessária "deformação coerente", que é a busca de uma resposta a uma interrogação que o mundo lhe dirige, o pintor adentra e se relaciona, correndo os riscos exigidos pela autêntica criação, com uma ausência que ele pode superar ou não. Trata-se de uma ausência de consistência, porque o pintor promove essa "deformação coerente" através da sua percepção que já é estilização, isto é, que quebra a "inacessível consistência das coisas" ao "[...] modular certos vãos, certas fissuras e fundos, alto e baixo, norma e desvio, quando certos elementos do mundo assumem valor de dimensão a que tudo o mais doravante há de se referir, em cuja linguagem haveremos de exprimi-lo" (MERLEAU-PONTY, 1960a, p. 88). Essa "deformação coerente" da percepção determina, segundo um sistema de equivalências que compõe o estilo de cada pintor, o sentido momentaneamente indeterminado, expressandoo na criação, na obra. Esse trabalho do pintor não deve ser subestimado pelos escritores, aconselha Merleau-Ponty. A linguagem da pintura ou seu sistema de equivalências cria ou abre sobre a tela um quase-espaço em que o espetáculo, já desprendido do mundo coerentemente deformado, é investido em cores; e um novo sentido aparece, vem à existência. A pintura nos ensina a gênese do sentido ao possibilitar que este venha imprimir-se no quadro. Por isso, e para que a obra de arte alcance a plenitude de nosso espírito, é preciso que ela "[...] seja outra coisa que existência consumada [...], que exceda o simples constar da existência dada" (MERLEAU-PONTY, 1960a, p. 92), e que "não exista em si como coisa", como obra acabada. A obra de arte, assim definida 
objetivamente, vai de encontro ao labor do pintor, que não é senão

[...] um homem em serviço, que toda manhã detecta no aspecto das coisas a mesma interrogação, o mesmo apelo a que jamais terá conclusivamente respondido. A seus olhos, a obra não está nunca terminada, mas sempre em curso, de modo que ninguém pode antepô-la ao mundo (MERLEAUPONTY, 1960a, p. 94).

A pintura busca pôr-se e seguir o curso do mundo, o fluxo das diferenciações, a contingência sensível; mesmo porque, o pintor está-no-mundo através do seu corpo. É com o seu corpo, enquanto entrelaçamento de visão e de movimento, que ele transforma o mundo em pintura, uma vez que "[...] toda percepção, toda ação que a supõe, todo uso humano do corpo, em suma, é já expressão primordial" (MERLEAU-PONTY, 1960a, p. 108). O que é encontrar, após a ameaça do não-sentido daquela "deformação coerente", um novo sentido, ou mais propriamente, um sobre-sentido. Não é inoportuno falarmos de sobre-sentido, pois essa expressão primordial, na medida em que se assenta nessa "deformação coerente", é um encontro e um movimentar-se pelas diferenças, pelos desvios, pelos perfis perceptivos, rumo ao depois da imediatidade e da indiferença dos objetos e das coisas em si mesmas. Essa expressão primordial pressupõe, necessariamente, que "o próprio do gesto humano" consiste em

[...] significar para além de sua mera existência de fato, em inaugurar um sentido, segue-se que qualquer gesto é comparável a qualquer outro, que formam todos uma única sintaxe, que cada qual é um princípio (e uma seqüência), que por não estar, como o evento, exaurido em sua diferença e para sempre concluso, prenuncia uma seqüência ou reincidência, fazendo-se sentir além da simples presença e mostrando-se por isso aliado ou cúmplice a todas as outras tentativas de expressão (MERLEAU-PONTY, 1960a, p. 109110). 
Pela sua transcendência de si ou expressividade, a pintura é comparável a um gesto humano que, por sua vez, é comparável a qualquer outro gesto. $\mathrm{E}$ tal como o gesto humano, não fechada em si, ela inaugura um sentido que lhe é sempre transcendente, pelo qual ela sobrevive e pode ser retomada pela posteridade como uma instituição ou aquisição cultural. Essa transcendência é propriamente uma capacidade de universalizar-se, de possuir uma vida universal e concreta.

Mas, do que é signo ou sobre o que fala, a linguagem que não diz? De antemão, "[...] a pintura jamais celebra outro enigma a não ser o da visibilidade" (MERLEAU-PONTY, 1975, p. 281). O que se deve entender por "enigma da visibilidade"? É que a pintura é contato com um Ser que "se mostra ao mesmo tempo que se esconde", que se cliva e está sempre indeterminadamente além de sua clivagem, misto de visível e de invisível, de dizível e de indizível. Nela, é "o próprio Ser mudo que vem a manifestar o seu próprio sentido" (MERLEAU-PONTY, 1975, p. 229). O sobre-sentido do quadro é, a bem dizer, a expressão do silêncio ontológico, selvagem. Quando a linguagem menos parece consigo mesma, ela é pintura. Quando a pintura vem a ser, no momento em que as coisas se tornam pintura, a linguagem as absorve.

O pintor, em sua "ruminação do mundo", não tem outra técnica a não ser o seu olhar e o seu mover-se. Ele se vê em seu mover-se, ele é vidente. Há, mesmo, um entrelaçamento do visível e do movimento da visão que nos

[...] impede de a concebermos como uma operação de pensamento que ergueria, diante do espírito, um quadro ou uma representação do mundo, um mundo da imanência e da idealidade. Imerso no visível por seu corpo, embora ele próprio visível, o vidente não se aproxima daquilo que vê: só se aproxima dele pelo olhar, abre-se para o mundo. E, por seu lado, esse mundo, de que ele faz parte, não é em si ou matéria (MERLEAU-PONTY, 1975, p. 278).

A visão e o movimento se exigem e exigem a correlação corpo-

Educ. e Filos., Uberlândia, v. 21, n. 42, p. 61-88, jul./dez. 2007. 
mundo. Enquanto movimento, não sou um espírito caminhando entre as coisas decretando-lhes determinações, tais como sua extensão no espaço, mas sou o meu corpo, na medida em que o meu movimento é a "seqüência natural e o amadurecimento de uma visão". Enquanto uma coisa é movida, o meu corpo se move. "Meu movimento se desdobra. Ele não está na ignorância de si, não é cego para si, irradia de um si" (MERLEAU-PONTY, 1975, p. 278). Ao mover-se, meu corpo sabe-se movente.

O enigma reside nisto: meu corpo é ao mesmo tempo vidente e visível. Ele, que olha todas as coisas, também pode olhar a si e reconhecer no que está vendo então o 'outro lado' do seu poder vidente. Ele se vê vidente, toca-se tateante, é visível e sensível por si mesmo (MERLEAU-PONTY, 1975, p. 278).

O corpo tem que se mover ao mover, tem que se ver ao ver, para confirmar sua soberania através das suas ações, que são a afirmação do "eu posso" - relação primordial entre sensibilidade e motricidade. O corpo é um si narcísico que se forma por "[...] inerência daquele que vê naquilo que ele vê, daquele que toca naquilo que ele toca, do senciente no sentido -, um si, portanto, que é tomado entre coisas, que tem uma face e um dorso, um passado e um futuro" (MERLEAU-PONTY, 1975, p. 278). Devido à sua mobilidade, visibilidade e vidência, o corpo insere-se no número das coisas que contam no espetáculo sustentado por ele mesmo, de tal forma que as coisas são um "anexo ou prolongamento" seu. Elas "[...] estão incrustadas na sua carne, fazem parte da sua definição plena, e o mundo é feito do próprio estofo do corpo" (MERLEAU-PONTY, 1975, p. 279). Isto significa que a pintura se faz nas próprias coisas. Ela é a apreensão desse mesmo estofo, ela nasce nessa membrura entre as coisas e meu corpo.

A "deformação coerente" da expressão primordial,

[...] esta visão devoradora, para além dos "dados visuais", abre uma textura do Ser cujas imagens sensoriais discretas são apenas as pontuações ou as cesuras, e que o olho habita

Educ. e Filos., Uberlândia, v. 21, n. 42, p. 61-88, jul./dez. 2007. 
como o homem habita sua casa [...]. O mundo do pintor é um mundo visível, simplesmente visível, um mundo quase louco, pois que é completo sendo, entretanto, meramente parcial. A pintura desperta e eleva à sua última potência um delírio que é a própria visão, já que ver é ter à distância, e que a pintura estende essa bizarra posse a todos os aspectos do Ser, que de alguma maneira devem fazer-se visíveis para entrar nela (MERLEAU-PONTY, 1975, p. 281).

A pintura é um questionamento de como as coisas se tornam visíveis ou plásticas, de como o olhar responde-lhes, de como alguma coisa, de repente, após a ameaça da ausência de significação, aparece no quadro (quase-espaço) como uma nova significação ou sobre-sentido1. "Mas, em todo caso, a interrogação da pintura visa a essa gênese secreta e febril das coisas em nosso corpo" (MERLEAU-PONTY, 1975, p. 282). É preciso, pois, que a visão do pintor seja um "nascimento continuado", porque a coisa não está esgotada em seu mostrar-se, em seu tornar-se visível num espaço pré-objetivo ou estético, espaço aberto no qual essência e existência, imaginário e real, visível e invisível, encontram-se embaralhados. Nesse espaço em que não valem nossas categorias, a pintura desdobra "o seu universo onírico de essências carnais, de semelhanças eficazes, de mudas significações" (MERLEAUPONTY, 1975, p. 283). Nesse espaço em formação ou quase-espaço da pintura não valem as leis abstratas da perspectiva ${ }^{2}$. Ele é uma desfiguração do espaço intelectualizado regido por leis físicas, que

1 E ainda, MERLEAU-PONTY (1975, p. 281): “É a própria montanha que, lá de longe, se mostra ao pintor, é a ela que ele interroga com o olhar. Que lhe pede ele exatamente? Pede-lhe desvelar os meios, apenas visíveis, pelos quais ela se faz montanha aos nossos olhos". Neste sentido, o que pinta o pintor? Ele pinta o se mostrar da montanha, os modos pelos quais o que se mostra mostra-se montanha, mas, para obter êxito, o pintor precisa desvelar as condições desse mostrar-se através do qual nos atinamos com alguma coisa.

2 A pintura clássica, que pretende ser tão convincente quanto as próprias coisas e oferecer aos nossos sentidos um espetáculo irrecusável, vale-se da perspectiva, justamente para realizar suas pretensões, porque através dessa técnica, a pintura

Educ. e Filos., Uberlândia, v. 21, n. 42, p. 61-88, jul./dez. 2007. 
a Dióptrica de Descartes privilegia e descreve. A Dióptrica, ao avaliar a natureza da imagem, por exemplo, considera que

[...] se o reflexo se parece com a própria coisa, é que age mais ou menos sobre os olhos como o faria uma coisa. Ele engana o olho, gera uma percepção sem objeto, mas que não afeta a nossa idéia de mundo. No mundo, há a própria coisa, e fora dele há esta outra coisa, que é o raio de luz refletido, e que tem com a primeira uma correspondência regulada, dois indivíduos, portanto, ligados de fora pela causalidade (MERLEAU-PONTY, 1975, p. 284).

A semelhança é um vínculo estabelecido pelo pensamento, ou seja, na verdade, a imagem não se parece com as coisas, e é essa a condição para representá-las através de figuras achatadas em um só plano, deformadas. A verdade da representação está no intelecto, que privilegia as propriedades matemáticas das coisas. Pelo contrário, conforme havemos dito, a relação de semelhança entre a imagem (a pintura) e as coisas é assegurada através do corpo do pintor. A pintura começa aqui, pois ela necessita da promiscuidade do vidente e do visível. Relativamente à noção de "visão", essa contradição continua. Para a Dióptrica,

[...] das coisas aos olhos e dos olhos à visão não passa nada mais que das coisas às mãos do cego e, das suas mãos, ao seu pensamento. A visão [...] é um pensamento que decifra estritamente os sinais dados no corpo [...]. Com muito mais razão, a imagem mental, a vidência que nos torna presentes àquilo que está ausente, não é nada parecido com uma abertura ao coração do Ser: é ainda um pensamento apoiado em indícios corporais (MERLEAU-PONTY, 1975, p. 285).

clássica imitaria a mesma realidade para todos os homens. Na verdade, tratavase para Merleau-Ponty, (1960a, p. 81) “[...] da invenção de um mundo dominado, possuído de parte a parte numa síntese instantânea" que foge à espontaneidade do olhar. 
Nesses termos cartesianos, em oposição ao que temos afirmado, a pintura em nada contribui para a definição do nosso acesso ao Ser. Na pintura, Descartes privilegia tudo o que nos remete à forma do objeto: o desenho e as linhas, por exemplo, em detrimento da cor. Por isso ele analisa os talhos-doces, pois estes "[...] nos dão uma apresentação do objeto pelo seu exterior ou envoltório" (MERLEAU-PONTY, 1975, p. 286). Eis uma geometrização da pintura. O espaço plástico deixa de ser aquele quase-espaço para se tornar um espaço geométrico, um espaço em si que regula, mediante as qualidades primárias dos objetos, tais como a extensão, o poder do desenho de tornar possível a representação da extensão e, em última instância, a própria pintura - a única aceitável.

É esse espaço sem esconderijo que, em cada um de seus pontos é, nem mais nem menos, o que ele é, é essa identidade do Ser que sustenta a análise dos talhos-doces. O espaço existe em si, ou, antes, é o em-si por excelência, sua definição é ser em si. Cada ponto do espaço existe, e é pensado aí onde existe, um aqui, outro ali; o espaço é a evidência do onde (MERLEAU-PONTY, 1975, p. 287).

Aqui, a pintura, para se fazer, tem necessidade do lugar, do onde, que ela deve apenas imitar, presa às referências visíveis, perspectivas e objetivas do onde. Ela não adentra na insegurança de um não-onde selvagem e ontológico, pelo contrário, ela busca, estrabicamente, o espaço que "repousa absolutamente em si", e que "[...] em toda parte é igual a si, homogêneo, e suas dimensões, por exemplo, por definição são substituíveis" (MERLEAU-PONTY, 1975, p. 285). Entretanto,

[...] se houvesse examinado esta outra e mais profunda abertura às coisas que as qualidades segundas nos proporcionam, notadamente a cor, como não há relação regulada ou projetiva entre elas e as propriedades verdadeiras das coisas, e como, no entanto, a mensagem delas é compreendida por nós, Descartes ter-se-ia achado diante 
do problema de uma universalidade e de uma abertura-àscoisas sem conceito, ter-se-ia visto obrigado a indagar como o murmúrio indeciso das cores pode apresentar-nos coisas, florestas, tempestades, enfim, o mundo, e talvez a integrar a perspectiva, como caso particular, num poder ontológico mais amplo (MERLEAU-PONTY, 1975, p. 286).

Temos também a cor como dimensão do Ser, como introdução à coisa e ao mundo. Isto significa que ela é signo ou acesso préconceitual à universalidade do Ser. A pintura se faz na diferenciação entre as cores e, é nessa contextura entre-cores que alguma coisa vem se mostrar pintura. "O retorno à cor tem o mérito de conduzir a um pouco mais perto do "coração das coisas": mas ele está para além da cor-envoltório como do espaço-envoltório" (MERLEAU-PONTY, 1975, p. 294). Através deste retorno, coloco-me num espaço-aquém daquele de que fala a Dióptrica. Na dimensão de cor estou num espaço "contado a partir de mim como ponto ou grau zero da espacialidade. Eu não o vejo segundo o seu invólucro exterior, vivoo por dentro, estou englobado nele" (MERLEAU-PONTY, 1975, p. 290). Conseqüentemente, "a visão do pintor não é mais um olhar sobre um exterior, relação "físico-óptica" somente com o mundo. $\mathrm{O}$ mundo não está mais diante dele por representação: antes, o pintor é que nasce nas coisas como por concentração e vinda a si do visível" (MERLEAU-PONTY, 1975, p. 294). O pintor nasce na e da deiscência do visível. O não-lugar da pintura é precisamente um paradoxo: é uma juntura por segregação, uma ausência plena e substancial, que não é vazio, uma fissura que não é separação. O seu lugar é precisamente este " $\mathrm{e}$ " ambivalente e indeterminado quando tomamos a relação entre $o$ visivel 'e' $o$ invisivel. A ausência de lugar como lugar é o "entre", o "intervalo", a "juntura", a "reversibilidade". E é pela reversibilidade de suas dimensões que se expressam reciprocamente, isto é, por sua profundidade, que podemos denominar o Ser através de uma "localidade" global como universalização do não-lugar para além de qualquer local. Nessa Localidade tudo está a um só tempo. Essa é a apresentação universal e pré-conceitual do Ser que a pintura nos dá. Doravante, 
[...] figurativa ou não, a linha, em todo caso, não é mais imitação das coisas nem coisa. É um certo desequilíbrio disposto na indiferença do papel branco, é um furo praticado no em-si, um certo vazio constituinte [...]. A linha não é mais, como em geometria clássica, o aparecimento de um ser sobre o vazio do fundo; é, como nas geometrias modernas, restrição, segregação, modulação de uma espacialidade prévia (MERLEAU-PONTY, 1975, p. 296).

"Ver" não é mais um pensamento que se mira num espelho; a visão não é mais simplesmente uma presença a si, pelo contrário, “[...] é o meio que me é dado de estar ausente de mim mesmo, de assistir de dentro a fissão do Ser, só no termo da qual eu me fecho sobre mim" (MERLEAU-PONTY, 1975, p. 298). Para encontrar em cada coisa individual, não um simples e imediato objeto, mas uma dimensão do Ser, uma vinda a si do próprio Ser (essa vinda a si que vem imprimir-se no quadro), é preciso que a visão tenha aquele fundo de ausência, que ela seja um resultado ou uma resposta àquela fissão. "Quer isto finalmente dizer que é próprio do visível ter um forro de invisível no sentido próprio, que ele torna presente como uma certa ausência" (MERLEAU-PONTY, 1975, p. 299). Esta "certa ausência" é constituinte da pintura, é aquele depois da "deformação coerente" em que ela se coloca, no qual a visão "é o encontro, como numa encruzilhada, de todos os aspectos do Ser" (MERLEAU-PONTY, 1975, p. 299), quando a visão alcança a plenitude da sua definição: “[...] esta precessão daquilo que é sobre aquilo que se vê e se faz ver, daquilo que se vê e se faz ver sobre aquilo que é, é a própria visão" (MERLEAU-PONTY, 1975, p. 299). A pintura torna-se linguagem, define-se ou vem a si como o tornar presente esse "forro de invisível", essa "certa ausência", que é, na verdade, a confirmação e o tornar presente a linguagem que já habita o sensível, a linguagem que é o "forro do ser". Devido a essa linguagem que habita as coisas, entende-se a impressão de alguns escritores e poetas para quem as coisas nos falam, são significantes, possuem uma voz; assim como, alguns pintores sentem-se olhados pelas coisas, porque a visão ,narcísica, também 
está naquilo que eles vêem. A "visão silenciosa cai na fala" e "a palavra, abrindo um campo nomeável e dizível, nele se inscreve", e metamorfoseia as estruturas do mundo visível, trazendo para o olhar o espírito. A visão e o vidente nascem por concentração de uma visibilidade geral e elementar que assegura a harmonia e a reversibilidade entre o visível e o vidente. Ao passo que a linguagem habita as coisas, porque "a linguagem é tudo, pois não é a voz de ninguém, é a própria voz das coisas, ondas e florestas" (MERLEAUPONTY, 1964, p. 204;). Isto é, há uma indiscernibilidade originária e ontológica entre essa "voz de ninguém" e as coisas, porque há um Logos que habita o Sensível, também indiscernivelmente. A pintura vem a si quando a visão consegue testemunhar não simplesmente as coisas em si, mas as coisas habitadas pela linguagem, porque esta é o invisível que habita o mundo, o invisível que precede e possibilita a visão e o próprio pensamento. Este é o limite e a virtude da Fenomenologia da percepção, e o começo de $A$ Prosa do Mundo: não é o cogito, ainda que tácito, que habita as coisas possibilitando conhecê-las; não há um cogito trabalhando secretamente no sensível assegurando-lhe o acesso e a racionalidade através de significações puras e $a$ priori; não há um cogito secreto em nossa experiência perceptiva e lingüística.

Porém, contrariamente ao discurso, a pintura não procura compreender-se, "conquistar o segredo de suas próprias invenções". Eis seu limite: "o homem não pinta o pintar, mas diz o dizer, e o espírito da linguagem tende a originar-se de si mesmo" (MERLEAU-PONTY, 1960a, p. 129). Emerge de toda uma profícua convergência entre pintura e linguagem, uma incontornável diferença, a saber, "a linguagem diz, e as vozes da pintura são vozes do silêncio" (MERLEAU-PONTY, 1960a, p. 130).

$$
\text { (...) }
$$

"Qual quadro, o romance exprime tacitamente" (MERLEAUPONTY, 1960a, p. 123). Enquanto experiências expressivas, pintura e linguagem encontram-se quando alcançam o silêncio - quando a pintura se faz como vozes do silêncio e a linguagem se faz linguagem indireta ou literatura. Vejamos, pois, essa virtude de descentramento e de desdobramento da linguagem em linguagem 
indireta, do signo em não-signo. Como alcançamos essa fala que resulta da ameaça da não-linguagem enfrentada pela linguagem, essa fala que está depois da linguagem, numa ausência de referenciais e de sentidos disponíveis? Acostumados a ouvir o questionamento por uma "linguagem antes da linguagem" defendida pela tradição intelectualista, perguntamos: há uma "linguagem depois da linguagem"? Se há, do que ela fala? Qual a validade do que digo sobre ela, isto é, como dizê-la sem negá-la? Essas são apenas as dificuldades mais imediatas. Mas, adentremos no mistério da linguagem, nessa derrière-linguagem, e não num cogito atrás da linguagem.

"A linguagem jamais se ocupa senão de si mesma [...]. O mistério é que, no momento mesmo em que a linguagem está assim obsedada por si própria, lhe é dado, como que por acréscimo, abrirnos a uma significação" (MERLEAU-PONTY, 1969a, p. 162). Esse poder de abertura da linguagem a uma significação não é um índice de sua fraqueza (ainda que a significação provenha de um desequilíbrio momentâneo), pelo contrário, esse poder nos indica que a linguagem atingiu a plena posse de si mesma, que não é sinônima de um fechamento em si.

Há, portanto, uma significação da linguagem, tanto mais evidente quanto mais nos entregamos a ela, tanto menos equívoca quanto menos pensamos nela, rebelde a toda posse direta, mas dócil ao encantamento da linguagem, sempre aí quando confiamos nela ao evocá-la, mas sempre um pouco mais longe que o ponto onde acreditamos circunscrevê-la (MERLEAU-PONTY, 1969a, p. 162).

Para apreendê-la em sua evidência, somente através de uma crença na linguagem, já que ela está também além dela mesma, inobservável, já que ela é "oblíqua e autônoma". Através da sua significação linguageira ou existencial, a linguagem está-aí evidente, porém sempre nos escapando quando tentamos possuíla diretamente. Por isso é que, tal como o tecelão, o escritor trabalha às avessas, isto é, procura adentrá-la indiretamente ao invés de 
possuí-la. De repente, quando se vê rodeado de sentido, é que ele se encontra naquela obliqüidade e autonomia. Estamos, então, condenados ao silêncio? "Se ela se furta a quem a procura e se entrega a quem renunciou a ela, não podemos considerá-la de frente, não resta senão pensá-la de viés" (MERLEAU-PONTY, 1969a, p. 163). Inegavelmente, há, aqui, um limite, qual seja, falaremos da linguagem, e, "não sendo a linguagem de que falaremos a que fala dela, o que dissermos não será sua definição suficiente" (MERLEAU-PONTY, 1960a, p. 163.). A linguagem possui um fundo essencial de indefinição sobre o qual se desenrola. Isso significa que o que podemos afirmar sobre ela, deixa para trás um subentendido - muito da vida da linguagem, do seu uso vivo. Não é ao explicá-la, decompô-la, deduzi-la ou fundá-la em algo que lhe é exterior (por exemplo, uma reflexão que a tomasse como tema) que encontraríamos a sua clareza própria. Essa clareza se manifesta quando alguém me fala e eu compreendo, quando a linguagem está plenamente possuída por si mesma. Essa clareza da compreensão significa que houve expressão, quando as palavras passam imperceptíveis em prol de uma significação que apreendemos como se fosse um pensamento nosso, quando temos a impressão de que estamos depois da linguagem ou do discurso. Essa clareza é de ordem perceptiva. A significação é "quasesensorial", ou seja, é uma figura destacada sobre o fundo de palavras. Em termos merleau-pontyanos, a analogia com a ordem perceptiva é muito oportuna:

[...] embora apenas as Abschattungen (perspectivas) da significação sejam tematicamente dadas, o fato é que, passado um certo ponto do discurso as Abschattungen, tomadas em seu movimento, fora do qual nada são, subitamente se contraem em uma nova significação: sentimos que algo foi dito, assim como, acima de um mínimo de mensagens sensoriais, percebemos uma coisa, embora, em princípio, a explicitação da coisa vá ao infinito (MERLEAU-PONTY, 1960b, p 148).

A expressão se realiza depois de "passado um certo ponto do 
discurso", sem que se discirna uma "fronteira" que tenhamos passado, muito embora sentimos que a tenhamos passado. A expressão é essa contração das perspectivas em uma nova significação sobre a qual nada sabemos, de antemão, e que nos é uma ausência. Entretanto, "[...] nada é mais convincente do que essa experiência, e não se trata de buscar em outro lugar, senão nela, o que a torna incontestável, de substituir a operação da fala por alguma pura operação do espírito" (MERLEAU-PONTY, 1969a, p. 164). A evidência da experiência expressiva diz respeito ao nascimento da significação na própria fala. O que MerleauPonty pretende com isso, "e essa é toda a filosofia", é

[...] tirar proveito dessa evidência, de confrontá-la com as idéias prontas que temos da linguagem, da pluralidade dos espíritos, trata-se de restabelecê-la justamente em sua dignidade de evidência, que ela perdeu pelo próprio uso da linguagem e porque a comunicação nos parece natural (MERLEAU-PONTY, 1969a, p. 164).

Isto é, é preciso chegar ao depois dessa aparência de naturalidade da comunicação, quando a linguagem se encontra desgastada pelo uso e transformada em idéias prontas; está nesse depois a dignidade da linguagem, e adentrá-lo significa restituir a expressividade lingüística. Enfim, "trata-se de devolver-lhe (a essa evidência), fornecendo-lhe um fundo conveniente sobre o qual possa se destacar, o que ela tem de paradoxal e até mesmo de misterioso - trata-se de conquistá-la como evidência" (MERLEAUPONTY, 1969a, p. 164-165). E a fala é este fundo. A fala, por não ser meramente uma prática imediata da linguagem disponível, mas o encontro e a confirmação do enigma que a linguagem traz dentro de si, é a melhor interrogação que dirigimos à linguagem, que, na verdade está dentro desta. É com esta interrogação que o escritor escreve. No momento em que a linguagem está ameaçada pela não-linguagem e o sentido pelo não-sentido, em que as perspectivas ainda não se contraíram em uma nova significação, o escritor e a literatura se fazem no enfrentamento dessa ameaça; eles provêm 
do devir ou da vinda a si da linguagem e do sentido, quando a um sobre-significante corresponde um sobre-sentido. Essa correspondência, em suma, é a própria literatura enquanto "experiência e invenção", enquanto exemplo do "uso vivo" da linguagem.

Trabalhar com a linguagem viva ou falante é sair da linguagem falada e do sentido sedimentado e adentrar numa ausência de signo e de sentido, momentânea ou não, quando estamos no limiar do não-sentido. É trabalhar com o subentendido ou com o avesso da linguagem. Mas de que modo? Eis o que faz um escritor autêntico: ele promove uma "torção secreta" das palavras (sinônima daquela "deformação coerente" que faz o pintor) através da qual ele sai das palavras adquiridas, do comum e do já conhecido. Essa "torção secreta" é uma diferenciação pela qual o escritor se faz e cria seu mundo (sua obra). Esta vem à existência como uma nova significação ou sobre-sentido destacado do fundo de sentido sedimentado. Por essa "torção secreta", ele me faz entrar em seu mundo ou reconhecer a diferença que o identifica - o que significa que o escritor teve o êxito de me fazer sentir essa mesma "torção secreta"; sem isso, ele e o seu mundo não se me apresentariam, isto é, não haveria literatura ${ }^{3}$. Com essa indispensável "torção

3 MERLEAU-PONTY (1969b, p. 18-19): “Graças aos signos sobre os quais o autor e eu concordamos, porque falamos a mesma língua, ele me fez justamente acreditar que estávamos no terreno já comum das significações adquiridas e disponíveis. Ele se instalou no meu mundo. Depois, imperceptivelmente, desviou os signos de seu sentido ordinário, e estes me arrastam como um turbilhão para um outro sentido que vou encontrar". Se o escritor consegue me conduzir por esse "desvio dos signos", como por um caminho, até o encontro de um outro e novo sentido que está depois da linguagem, isto é, se ele me faz passar desta para o sentido, a tal ponto que as palavras se me tornam imperceptíveis, então, tenho a mesma experiência da expressão que ele compartilhamos daquele uso vivo da linguagem enquanto experiência e invenção; encontramo-nos na obliqüidade da linguagem, quando tenho a impressão de criar Stendhal, de ser Stendhal ao lê-lo, "mas é porque, primeiramente, ele soube me instalar nele". Eis o poder da expressão bem sucedida. Stendhal é um mundo, ou me apresenta um novo e recuperado mundo, que acredito criar ao ser tomado e modificado por sua expressão que 
secreta" que visa a expressividade da linguagem, o escritor lida com o apagamento ou esquecimento da linguagem plenamente possuída por si mesma, e a compreensão que terei dele depende da sua capacidade de criar em mim e de me fazer sentir a angústia e os riscos da criação (que deve passar, necessariamente, pela ameaça da não-linguagem, do não-sentido), isto é, sentir esse apagamento e esse esquecimento de uma linguagem tornada plena e virtuosa. Essa linguagem em demasia, incomoda; sua leveza a torna quase inapreensível. E é essa leveza que o escritor busca e trabalha.

A expressão (ou sua virtude de exprimir-se) se realiza sobre esse fundo de esquecimento. Isto quer dizer que a linguagem é inapreensível no ato de expressão. Neste momento, o esquecimento é o procedimento de descentramento da linguagem rumo à linguagem indireta, assim como, de desdobramento da linguagem em seu avesso, quando passamos dos signos ao sentido, "quando sou cativado por um livro", quando estamos na ausência de signo como sobre-significante. Pois

essa é exatamente a virtude da linguagem: é ela que nos lança ao que ela nos significa; ela se dissimula a nossos olhos por sua operação mesma; seu triunfo é apagar-se e dar-nos acesso, para além das palavras, ao próprio pensamento do autor, de tal modo que retrospectivamente acreditamos ter conversado com ele sem termos dito palavra alguma, de espírito a espírito (MERLEAU-PONTY, 1969b, p. 16).

E é esta a perfeição da linguagem: no momento em que ela

subverte as relações ordinárias entre os signos e o sentido neles sedimentado. Esta subversão nos apresenta um novo acesso a uma nova apresentação do mundo, ou seja, ela nos apresenta o mundo de um novo jeito, ela o recria. É deste modo que Stendhal me faz encontrá-lo e que ele se torna uma presença em suas palavras, quando, por ele mesmo, arrebatado de minha indiferença, não consigo distinguilo da sua expressão; ele se faz como significação realizada ou existência transcendente aos signos, como o excesso que suas palavras não-dizem.

Educ. e Filos., Uberlândia, v. 21, n. 42, p. 61-88, jul./dez. 2007 
passa despercebida, em que ela é indireta, ela nos diz algo, atinamos com uma nova significação que até então nos era estranha ${ }^{4}$. No momento da leitura, essa significação nova e estranha estava além da minha linguagem e do meu pensamento, eu fui lançado a ela pela intenção significante de outrem, " [...] assim como a percepção nos lança às coisas mesmas para além de uma perspectiva da qual só me dou conta depois" (MERLEAU-PONTY, 1969b, p. 21). Através do seu esquecimento e do seu descentramento, quando ela está pelo avesso, a linguagem nos conduz às coisas mesmas. E é por exigir dela essa "torção secreta" em que ela se abre e se desdobra em avesso, que a literatura não é mais uma linguagem que tem significação, mas que é significação, isto é, acesso às coisas mesmas. Nesses termos, ter uma significação seria postular uma "linguagem antes da linguagem", conseqüentemente, a literatura está na linguagem em formação e falante, ela nos dá a gênese e o devir do sentido, porque ela é o devir ou a vinda a si da linguagem que se reordena após a ameaça da perda de centro e de equilíbrio. A literatura é o resultado e o testemunho de uma linguagem que começa e se fundamenta em si mesma, originária e criativa, sem um texto ou caminho prévios para se guiar, porém fazendo-se de caminho à medida que avança para aquilo que ainda não sabemos nem pensar nem dizer. Caminho que é relação com a ausência e que não sabemos, de antemão, se nos conduzirá a algum lugar. Trilhá-lo é acreditar na linguagem sem questionar sua possibilidade, abandonar-se a ela, deixar-se encantar por ela; eis o escritor e o homem feliz. Estes, não se perguntam, "antes de falar, se a fala é possível, não se detêm na paixão da linguagem que é ser obrigada a não dizer tudo se queremos dizer alguma coisa" (MERLEAUPONTY, 1969c, p. 201-202). Não trilhá-lo é pensar a linguagem, retirando-lhe sua vida ao retirá-la do mundo. O pensamento

4 “Não se fará idéia do poder da linguagem enquanto não se tiver reconhecido essa linguagem operante ou constituinte que aparece quando a linguagem constituída, subitamente descentrada e privada de seu equilíbrio, ordena-se de novo para ensinar ao leitor - e mesmo ao autor - o que ele não sabia pensar nem dizer" (MERLEAU-PONTY, 1969b, p. 22). 
constrói-lhe muros muito parecidos com os das universidades (que privilegiam uma linguagem oficial), esquecendo-se de que "[...] a filosofia não é a passagem de um mundo confuso a um universo de significações fechadas. Ao contrário, ela começa com a consciência daquilo que corrói e faz ruir, mas também renova e sublima nossas significações adquiridas" (MERLEAU-PONTY, 1969 b, p. 25-26). Em outros termos, o pensamento se esquece que a filosofia é também uso vivo da linguagem, que ela está na vida e no mundo fora desses muros. Esse esquecimento é o fundamento do seu dogmatismo. Eis porque "precisamos pensar a consciência nos acasos da linguagem" e

“[...] compreender que a linguagem não é um empecilho para a consciência, que para esta não há diferença entre o ato de alcançar a si mesma e o ato de se exprimir, e que a linguagem, no estado nascente e vivo, é o gesto de retomada e de recuperação que me reúne a mim mesmo e aos outros" (MERLEAU-PONTY, 1969b, p. 26).

Afirmar que a consciência se alcança em sua expressão, é afirmar uma subjetividade indissociável da expressão ou a existência do sujeito falante, justamente aquele que acredita na linguagem, que se abandona a ela, deixando-se desfazer e refazer, e que, quando fala, não se representa os meios para isto. Há um "eu falo" que se atinge num sistema de expressão que é o avesso do sistema de expressão oficial que tem uma história objetiva. Esse "eu falo" é testemunha de que a linguagem possui interior, no qual ele está, e deste dentro, ele diz a linguagem exercendo-a. Dito de outro modo, sei que eu digo; a linguagem me proporciona esse saber e essa consciência. Essa consciência, é bom que digamos, não é definida pelo pensamento, não é uma consciência ou uma esfera de puras significações anterior à linguagem, mas um "eu posso" indiscernível de um "eu falo", um entrelaçamento de pensamento e de fala. No momento em que escrevia as suas Meditações, Descartes era esse sujeito falante (e não um puro pensamento que nos seria inacessível). Isto significa que ele era 
comparável ao escritor, que ele fazia uso da "maravilha da linguagem", que consiste em se fazer esquecer para expressar ou trazer à existência uma significação nova, no caso, o cogito. Este é então um "cogito verbal" apresentado através do "sentido das palavras e do elo entre as idéias", isto é, "[...] eu só apreendi meu pensamento e minha existência através do meio da linguagem, e a verdadeira fórmula deste Cogito seria: 'se pensa, se é' “ (MERLEAUPONTY, 1945, p. 459). Se digo isto, e mesmo se tudo o que digo supõe a linguagem, "isso não invalida o que digo, isso revela apenas que a linguagem se toca e se compreende ela mesma, isso mostra apenas que ela não é objeto, que ela é suscetível de uma retomada, que é acessível do interior" (MERLEAU-PONTY, 1969b, p. 35). Com a descoberta dessa linguagem interior à linguagem, com a qual trabalha o escritor, estamos aquém da sua objetivação científica. Estamos na deiscência da linguagem, em uma linguagem descentralizada, indireta, enfim, numa linguagem que é uma potência "de fazer existir o expresso, de abrir caminhos, novas dimensões, novas paisagens para o pensamento". E é exatamente isto que caracteriza uma obra bem sucedida, uma criação autêntica, cujo excelente exemplo são as próprias Meditações, na medida em que, nela, "o sentido introduzido no espírito do leitor excede a linguagem e o pensamento já constituídos e se exibe magicamente durante a encantação lingüística" (MERLEAU-PONTY, 1945, p. 460). Agora estamos em condições de dizer que o cogito que apreendemos lendo Descartes está depois da linguagem e do pensamento. Através das suas Meditações, é para este depois que o Descartes escritor nos conduz; sem o que nos seria impossível compreendê-lo e retomá-lo hoje. Isto é possível, dito de outro modo, porque as verdadeiras Meditações, assim como o verdadeiro cogito, não se resumem e não se extinguem no que está pensado e no que está dito. Em um sentido bem mais radical e novo, o verdadeiro cogito (aquele que não só apreendemos lendo Descartes, mas que nos permite lê-lo e, assim, permite a compreensão intersubjetiva) não é o pensamento, mas o impensado, o pensamento que não se possui plenamente, a não-coincidência do pensamento consigo mesmo, o pensamento que se ultrapassa na fala, que se eterniza 
em verdade através da temporalidade da fala e que possui uma espessura temporal. Em termos merleau-pontyanos,

[...] o Cogito que nós obtemos lendo Descartes [...] é portanto um Cogito falado, posto em palavras, compreendido nas palavras e que, exatamente por essa razão, não alcança sua meta, já que uma parte de nossa existência, aquela que está ocupada em fixar conceitualmente nossa vida e em pensá-la como indubitável, escapa à fixação e ao pensamento" (MERLEAU-PONTY, 1945, p. 460).

Sob esse cogito encontramos um "cogito tácito"; era este que Descartes visava e que comandava todos os seus esforços de expressão. Portanto, este é o verdadeiro cogito, aquele que, emergindo da não-posse, da não-coincidência e da transcendência de um $e u$ descentralizado (misto indiscernível de pensamento e de impensado, de reflexão e de irrefletido), é uma existência que está depois do pensamento e da linguagem adquiridos, é uma "experiência de mim por mim" ou o próprio impensado. Nesses termos, Merleau-Ponty (1945, p. 462) afirma que "[...] o Cogito tácito, a presença de si a si, sendo a própria existência, é anterior a toda filosofia [...]. Aquilo que se acredita ser o pensamento do pensamento, como puro sentimento de si, não se pensa ainda e precisa ser revelado".

Como a filosofia pode revelar o que não se pensa, essa espontaneidade? Não é, certamente, posicionando-se na linguagem e, muito menos, no pensamento como instância anterior à linguagem, mas, depois deles e, em sentido mais radical, depois de si mesma, quando a filosofia, descentrada e correndo os riscos desse descentramento, é não-filosofia ou literatura. É nisto que consiste, finalmente, a reabsorção da não-filosofia. Encontrada nesse depois fundamental, eis o estatuto filosófico, e mesmo metafísico, da existência, da não-filosofia que jamais deixou de levar uma "vida clandestina" na literatura enquanto avesso dos grandes sistemas filosóficos tradicionais (MERLEAU-PONTY, 1948). Cumpre-nos, pois, pensar o estatuto propriamente filosófico daquela "deformação coerente" e daquela "torção secreta" da expressão, 
cujos exemplos, a filosofia encontra voltando-se para a pintura, para a literatura, para as artes em geral, enfim, para os saberes que têm ciência da sua própria expressão. Nesse sentido, aquela história do subentendido será uma história dessa "deformação coerente" e dessa "torção secreta" ao longo da história sedimentada da filosofia. No avesso desta há, portanto, uma história da metafísica, da nãofilosofia ou da existência determinada por sua facticidade. Tratarse-á, nessa história do avesso, de encontrar, através de um discurso "da" criação, um discurso que "é" criação, no sentido essencialmente radical do termo, ou seja, um discurso ou saber que não apenas tem ciência da sua própria expressão, mas que 'é' ciência da sua própria expressão, isto é, ontologia. Para ser a ciência da sua própria expressão, a filosofia deve ser a elaboração das "noções que devem substituir a de subjetividade transcendental, as de sujeito, objeto, sentido". E, assim, promover uma reforma do entendimento através de uma radical "torção secreta" descentralizadora, de tal modo que "[...] a definição da filosofia comportaria a elucidação da própria expressão filosófica [...] como ciência da pré-ciência, como expressão do que está antes da expressão e que a sustém por trás" (MERLEAU-PONTY, 1964, p. 221). À medida que a filosofia alcança a sua definição - que é ser elucidação da sua própria expressão -, ela vai se tornando essa "ciência da pré-ciência", ou seja, quanto menos a filosofia se parece consigo mesma, com maior excelência, ela alcança o que a sustém por trás, aquilo depois dela que está em silêncio. Eis o paradoxo e o problema que lhe definem: "[...] como é que toda filosofia é linguagem e consiste, porém, em reencontrar o silêncio" (MERLEAU-PONTY, 1964, p. 267); e não transpô-lo ou eliminá-lo. Ora, esse subentendido e esse silêncio intransponível que a sustém por trás é o próprio Sensível. É preciso perguntar: como a filosofia pode ser a expressão do que está antes dela, do silêncio fenomenológico, do silêncio que sempre viveu uma "vida clandestina" na história oficial da filosofia? Fazer a "história do subentendido" é, portanto, fazer a história desse silêncio. O que significa isto? É fazer uma história dos momentos em que a filosofia foi criação, é pensar a filosofia como criação (quando ela menos se pareceu consigo mesma, quando ela mais pareceu literatura), mas 
não como uma criação (Gebilde) "repousando sobre si mesma". Isto seria

“[...] uma criação que se propõe exprimir em Gebilde o que é von selbst (o Lebenswelt) que, portanto, se nega a si mesma como pura criação [...]. Trata-se de uma criação que é evocada e engendrada pelo Lebenswelt como historicidade operante, latente, que a prolonga e dela dá testemunho" (MERLEAUPONTY, 1964, p. 227-228).

O que está em silêncio e latente na história da filosofia é o Lebenswelt, que exige que a filosofia seja criação que, nascida nele, o prolongue e o testemunhe, isto é, ele contém "[...] tudo o que será dito, deixando-nos, todavia, a tarefa de criá-lo" (MERLEAU-PONTY, 1964, p. 223-224). Nesse sentido, a filosofia será a "ciência da préciência", a "expressão do que está antes da expressão e que a sustém por trás", quando ela tematizar o que permanece não tematizado em si mesma, quando ela descentralizar-se em seu avesso. Isto é, lhe é exigido que ela retome o Lebenswelt, porque "tudo o que dizíamos e dizemos o implicava e o implica. Ele estava ali, precisamente, como Lebenswelt não tematizado". E porque "entre o Lebenswelt como Ser universal e a filosofia como produto extremo do mundo, não há rivalidade ou antinomia: é ela que o desvela" (MERLEAU-PONTY, 1964, p. 224, grifo nosso). E isto, a arte lhe mostrou. Então,

“[...] a arte e a filosofia em conjunto são justamente não fabricações arbitrárias no universo do espiritual (da cultura), mas contato com o Ser na medida em que são criações. O ser é aquilo que exige de nós criação para que dele tenhamos experiência. Fazer a análise da literatura neste sentido: como inscrição do Ser" (MERLEAU-PONTY, 1964, p. 251).

Não chegamos ao Ser senão através da criação na qual ele vem se inscrever. Em nossas autênticas criações o Ser está inscrito e reafirmado, ainda que subentendido e silenciosamente. É por este motivo que, retomando aquela historicidade latente da criação 
filosófica nascida no Lebenswelt, a filosofia, enquanto história do seu nascimento, da sua criação e dessa inscrição do Ser, igualar-seá e constituir-se-á como discurso do Lebenswelt (aquele "Logos mais fundamental que o do pensamento objetivo"), como literatura enquanto discurso da própria vida, imerso na existência e no qual a existência está imersa, e que, enquanto criação, está sempre depois da cultura, revivificando-a. Trata-se de mostrar e de ultrapassar "[...] a distância entre a física e o ser da Physis, entre a biologia e o ser da vida, trata-se de efetuar a passagem do ser em si, objetivo, ao ser do Lebenswelt" (MERLEAU-PONTY, 1964, p. 220), a um universo da Weltlichkeit do Geist, e sair do "infinito como infinito objetivo" dos cartesianos, e retornar ao infinito da Offenheit (abrimento, abertura) do Lebenswelt. "Isto quer dizer que devo ainda, através das objetivações da lingüística, da lógica, reencontrar o logos do Lebenswelt"5 (MERLEAU-PONTY, 1964, p. 221), quando a filosofia, enquanto criação radical, é Urhistorie, erste Geschichtilichkeit (história originária, historicidade primeira Husserl), ou seja, desvelamento da "[...] história orgânica sob a historicidade de verdade, instituída por Descartes como horizonte infinito da ciência" (MERLEAU-PONTY, 1964, p.221).

"A filosofia do sensível como literatura"6 é a narrativa do devir

5 Este logos é também chamado de Logos endiathetos ("no sentido de antes da lógica"), que nos permite reencontrar esse mundo do silêncio prévio e nos permite fazer uma "filosofia do Lebenswelt" como desvelamento dele.

6 Sugestivo título de uma "nota de trabalho" de Merleau-Ponty, na qual aquilo que se apresenta inefável e incomunicável para a ciência é, justamente, literatura. Para a ciência, a vida é indizível, mas porque "a vida nada inspira ao homem que não é escritor". E "o sensível, como a vida, é um tesouro sempre cheio de coisas a dizer para aquele que é filósofo (isto é, escritor)" (MERLEAU-PONTY, 1964, p. 305). Para que ela reconquiste o ser bruto ou selvagem, a filosofia deve cumprir o seu voto de radicalismo, qual seja, igualar-se à não-filosofia como literatura, como "desenraizamento da filosofia objetiva". Isto significa tomar a linguagem não como uma "máscara sobre o Ser mas, se soubermos apreendê-la com todas as suas raízes e com toda a sua floração, o mais válido testemunho do Ser" (MERLEAU-PONTY,1964, p. 167). A “obra” inteira do filósofo consiste no esforço absurdo para escrever esse testemunho e contato com o Ser; “ [...] não o disse nem saberia dizê-lo, pois que é silêncio. Então, recomeça..." (MERLEAU-PONTY,1964, p. 166). 
do sentido, da deiscência e da clivagem originárias do Ser, realizando uma arqueologia ou história do sentido e do Ser como genealogia da lógica; só assim, ela pode ser a "reconquista do ser bruto ou selvagem". Porque há uma "Memória do Mundo", isto é, porque "o ser que foi não pode deixar de ter sido", essa "Memória" é o verdadeiro horizonte infinito da ciência, e neste sentido, ele não está no passado separado do presente, o Urstümlich (original caráter de ser primeiro) e o Ursprünglich (originário - caráter de provir da origem) não pertencem ao passado como mero acontecimento, estes são encontrados no presente, na carne do mundo e, por isso, indicam um "sempre novo" e um "sempre o mesmo". "O sensível, a Natureza, transcendem a distinção passado-presente, realizam uma passagem por dentro um ao outro. Eternidade existencial. O indestrutível, o Princípio bárbaro" (MERLEAU-PONTY, 1964, p. 321)7 (aquele do qual falava Schelling) sustenta nesse sempre original e originário presentes, a sua resistência em ser reabsorvido. Essa "eternidade existencial" que define o Ser, não pela atualidade imediata, mas pela presença, pela totalidade inapreensível, pelo não-Lugar que subverte as relações ordinárias do espaço-tempo, pela reversibilidade e produtividade inesgotável, é o próprio depois como horizonte original e originário. Essa "eternidade existencial" é a desse Princípio encarnado - misto indiscernível de fato e de essência, de conteúdo e de forma, de visível e de invisível, de sensível e de sentido, que fundamenta a reversibilidade do silêncio e da fala, do signo e da significação, ultrapassando, com isto, o caráter problemático e paradoxal da passagem do sentido perceptivo para o sentido lingüístico. Como a filosofia pode reabsorver esse Princípio imanente ao Sensível senão respondendo-lhe ou pondo-se à escuta desse Ser que fala em nós, senão reconquistando-se como essa Voz

7 Esse Princípio fez descer ao Sensível, a metafísica na forma de uma bárbara produtividade do sentido. A arqueologia da gênese ou a história do sentido, do seu vir-a-ser na deiscência diferenciadora do originário, são, de certo modo, uma metafísica do Sensível ou metafísica estética.

Educ. e Filos., Uberlândia, v. 21, n. 42, p. 61-88, jul./dez. 2007. 
que "não é a voz de ninguém", porque é "a própria voz das coisas, ondas e florestas", isto é, sendo o Ser falando em nós, a "expressão muda de si" ou criação? "Criação que é, ao mesmo tempo, reintegração do ser: pois não é criação no sentido de qualquer um dos Gebilde que a história fabrica: sabe-se Gebilde e quer-se ultrapassar enquanto pura Gebilde, reencontrar a sua origem. É, portanto, criação em sentido radical" (MERLEAU-PONTY, 1964, p. 250-251). Reencontrar a sua origem é des-figurar esteticamente o onde e o quando e retornar à "inauguração do onde e do quando", é encontrar a metafísica como carne, ou seja, como "[...] possibilidade e exigência do fato, numa palavra, facticidade, o que faz com que o fato seja fato. E também simultaneamente, o que faz com que tenham sentido, que os fatos parcelados se disponham em torno de alguma coisa" (MERLEAU-PONTY, 1964, p. 184).

\section{Referências}

BARBARAS, R. Le tournant de l'expérience: recherches sur la philosophie de Merleau-Ponty. Paris: J. Vrin, 1998.

De l'être du phénomène. Paris: Jérôme Millon, 1991.

BARBARAS, R.; COURT, R. Phénoménologie et esthétique. Paris: Encre Marine, 1998.

BONFAND, A. L'expérience esthétique à l'épreuve de la phénoménologie. Paris: PUF, 1995.

CAVALLIER, F. Premières leçons sur «L'Oeil et l'Esprit» de MerleauPonty. Paris: PUF, 1998.

BLANCHOT, M. L'espace littéraire. Paris: Gallimard, 1955.

BONAN, R. Premières leçons sur «L'Esthétique» de Merleau-Ponty. Paris: PUF, 1997. 
CAPALBO, C. A Filosofia de Maurice Merleau-Ponty: Historicidade e Ontologia. Londrina: Edições Humanidades, 2004.

. A Fenomenologia dialética do conhecimento e do vivido. In: Revista Brasileira de Filosofia, Rio de Janeiro. v. XXXVII, Fasc. 149, p. 16-30, Jan./Mar., 1988.

CHAUÍ, M. de S. Experiência do Pensamento: ensaios sobre a obra de Merleau-Ponty. São Paulo: Martins Fontes, 2002.

DÉLIVOYATZIS, S. La dialectique du phénomène: sur Merleau-Ponty. Paris: Méridiens Klincksieck, 1987.

HAAR. M. La philosophie française entre phénoménologie et metaphysique. Paris: PUF, 1999.

LEFEUVRE, M. Merleau-Ponty au delà de la phénoménologie. Du corps, de l'être et du langage. Paris: Librairie Klincksieck, 1976.

LEFORT, C. Sur une colonne absent: écrits autour de Merleau-Ponty. Paris: Gallimard, 1978.

MANTOVANI, H. J. Sobre-escritos. Rio de Janeiro: Câmara Brasileira de Jovens Escritores, 2006.

MERLEAU-PONTY, M. O olho e o espírito. In: Os Pensadores. Vol. XLI. São Paulo: Editora Abril, 1975. L'algorithme et le mystère du langage (1969a). In: _. La Prose du Monde. Paris: Gallimard, 1969. La science et l'expérience de l'expression (1969b). In: . La Prose du Monde.

La perception d'autrui et le dialogue (1969c). In: La Prose du Monde.

Educ. e Filos., Uberlândia, v. 21, n. 42, p. 61-88, jul./dez. 2007 
Le visible et l'invisible. Paris: Gallimard, 1964.

Le langage indirect et les voix du silence (1960a).

In: . Signes. Paris: Gallimard, 1960.

Sur la phénoménologie du langage (1960b).

In: . Signes. Paris: Gallimard, 1960.

Le métaphysique dans l'homme. In: Sens et non-sens. Paris: Nagel, 1948.

Phénoménologie de la Perception. Paris: Gallimard, 1945.

MOUTINHO, L.D.S. Tempo e sujeito - O transcendental e o empírico na fenomenologia de Merleau-Ponty. In: Dois Pontos: Temporalidade na Filosofia Contemporânea. v. 1, n. 1, p.11-57, 2004.

MÜLLER, M. Merleau-Ponty: acerca da expressão. v. 122. Porto Alegre: EDIPUCRS, 2001

RAINVILLE, M. L'expérience et l'expression: essai sur la pensée de Maurice Merleau-Ponty. Montreal: Éditions Bellarmim, 1998.

RICHIR, M.; TASSIN, E. Merleau-Ponty: phénoménologie et expériences. Grenoble: Jérôme Millon, 1992.

STRASSER, S. Réhabilitation de l'intériorité. Revue Philosophique de Louvain-

v.4, n.64, p. 502-520, nov., 1986.

THIERRY, Y. Du corps parlant: le langage chez Merleau-Ponty. Bruxelas: Éditions Ousia, 1987. 
WALLOT, H. L'accès au monde littéraire ou éléments pour une critique littéraire chez Maurice Merleau-Ponty, précédé de Une philosophie de la perception, Sherbrooke. Québec: Éditions Naaman, 1977.

Data de Registro 03/04/07

Data de Aceite 12/05/07

Educ. e Filos., Uberlândia, v. 21, n. 42, p. 61-88, jul./dez. 2007. 